\title{
ORGANOGÊNESE E TRANSFORMAÇÃO GENÉTICA DE MARACUJÁ AMARELO (Passiflora edulis f. flavicarpa DEG.) COM OS GENES CMe-ACO1 AS E nptII VIA Agrobacterium tumefaciens
}

\author{
ORGANOGENESIS AND GENETIC TRANSFORMATION OF YELLOW \\ PASSION FRUIT (Passiflora edulis $f$. flavicarpa DEG.) WITH THE GENES \\ CMe-ACO1 AS AND nptII THROUGH Agrobacterium tumefaciens
}

\author{
Larissa Macedo WINKLER \\ Orientador(a): Profa. Dra. Marguerite QUOIRIN \\ (Departamento de Botânica)
}

\begin{abstract}
RESUMO
O Brasil é o principal produtor mundial de maracujá - amarelo (Passiflora edulis f. flavicarpa Deg.). Seus frutos, de grande valor nutricional e farmacêutico são comercializados in natura e industrializados, garantindo o abastecimento do mercado interno e exportação. Contudo, seus frutos perdem grande quantidade de água durante o processo de maturação, conferindo à eles um aspecto de murcha em poucos dias, além de aumentar a fragilidade durante o transporte. Assim, o presente trabalho teve como principal objetivo, introduzir em tecidos desta espécie o gene que codifica para a enzima ACCO, em orientação antisense, via Agrobacterium tumefaciens. Esta enzima é responsável pela conversão do ácido 1-carboxílico -1 - aminociclopropano (ACC) em etileno, promovendo a maturação dos frutos. Como controle do processo de transformação, foi utilizado o gene nptll, que confere resistência ao antibiótico canamicina e que foi introduzido com sucesso nesta espécie em trabalhos anteriores. A transformação genética só é obtida com sucesso, se os explantes potencialmente transgênicos adquirirem aptidão para regenerar uma nova planta. Neste sentido, dois experimentos de organogênese foram realizados. Neles avaliou-se o efeito da idade fisiológica dos explantes (jovem e adulto); da posição de cultivo dos explantes (abaxial e adaxial) e o efeito da citocinina BAP: 1,$0 ; 1,5$ e 2,0 mg. $\mathrm{L}^{-1}$ na porcentagem de explantes com gemas, no número médio de gemas por explante, número médio de folhas por explante, comprimento médio das folhas, comprimento da haste principal e porcentagem de explantes que formaram calos. Os experimentos foram realizados sob delineamento experimental inteiramente casualizado, com quatro repetições de cada tratamento e dez explantes por parcela. A concentração 1,5 mg. $\mathrm{L}^{-1}$ de BAP promoveu os melhores resultados para todas as variáveis avaliadas, em ambas as posições de cultivo do explante e para tecidos jovens e adultos. Foi observada formação excessiva de calos na concentração de 2,0 mg. $\mathrm{L}^{-1}$ de BAP. Explantes foliares jovens, oriundos de sementes, regeneraram gemas adventícias em $50,22 \%$ dos casos após 30 dias de cultivo, em ambas as posições do explante no meio de cultura. Já os genótipos IAPAR 309, 156 x 123 e 352 (material adulto), apresentaram maior porcentagem de explantes regenerados quando estes foram cultivados na posição adaxial. $O$ alongamento e enraizamento dos brotos foram obtidos em ambos os tratamentos: MS e MS/2 + $1 \mathrm{mg} \cdot \mathrm{L}^{-1} \mathrm{de} \mathrm{GA}_{3}$. No entanto, o segundo tratamento resultou em maior comprimento de haste (3,73 cm), número médio de raízes por plântula $(2,08)$ e comprimento de raízes $(6,64 \mathrm{~cm})$ após 60 dias de cultivo. Nos ensaios com Agrobacterium, apenas uma planta de seis regeneradas e enraizadas em meio seletivo apresentou o gene antisense da ACCO, com uma eficiência de transformação de $1,43 \%$. Para o gene nptll esta eficiência foi de 4,3\%. Estes resultados foram confirmados pela técnica de PCR. Uma análise colorimétrica de frutos comerciais foi realizada e permitiu a classificação destes frutos em três grupos: predominantemente verde, predominantemente colorido e totalmente colorido. A produção de etileno e atividade enzimática da ACCO foi avaliada, mostrando que o maracujá amarelo é produtor intermediário de etileno e que a atividade enzimática da ACCO é limitada, necessitando de cofatores para sua atividade máxima.

Palavras-chave: Maracujá; organogênese; Agrobacterium; etileno; ACCO.
\end{abstract}

\begin{abstract}
Brazil is the main world producer of yellow passion fruit (Passiflora edulis f. flavicarpa). Fruits have a great nutritive and pharmaceutic value. They are commercialized in natura and industrialized for national market and exportation. Passion fruits present a high loss of water during fruit ripening, what is a concern for transport. In order to improve fruit quality and storage life, experiments were carried out for regeneration of plants from leaf explants of Passiflora edulis and for introduction of an antisense melon ACCoxidase gene (LEM1) via Agrobacterium tumefaciens strain carrying binary vectors. During climateric fruits ripening process, like yellow passionfruit, 1-carboxylic-1-aminocyclopropane (ACC) is converted into ethylene by the action of ACCoxidase enzyme. Two regeneration experiments were conducted, using Murashige and Skoog (1962) as basic medium. The effect of several factors was evaluated: physiological age of the explants (juvenile and adult), position of the explant on culture medium (with abaxial or adaxial face in contact with the medium), and three concentrations of benzyladenine (BAP) $(1.0,1.5$ and $\left.2.0 \mathrm{mg} \cdot \mathrm{L}^{-1}\right)$. The following data were recorded: percentage of regenerating leaf explants, mean number of buds per explant, mean number of leaves, mean length of the regenerated shoots and percentage of explants forming calli. Every experiment was repeated twice, each treatment had four repetitions of ten leaf explants each. The concentration of $1.5 \mathrm{mg} \mathrm{L.}^{-1}$ originated the best results for all the recorded datas for both positions and for juvenile and adult material. Callogenesis was high in the presence of 2 mg.L-1 BAP. For juvenile material grown from seeds, $50,22 \%$ of the explants formed adventitious buds by organogenesis for both positions of the explants. For adult material, IAPAR genotypes 309, $156 \times 123$ and 352 originated the highest percentages of adventitious buds when cultivated with adaxial face in contact with the medium. Elongation and rooting of the regenerated shoots were obtained in the presence of MS medium or half-strength salts of MS medium and $1 \mathrm{mg} . \mathrm{L}^{-1}$ of gibberellic acid. However, stem size, mean root number, and size were higher on the half strenght of MS salts. Through transformation experiments, leaf explants were co-cultured with disarmed A. tumefaciens vector PGA643 carrying LEM1 gene and EHA101 strain containing a plasmid harbouring a NOS/NPTII gene. Three plants among nine growing in the presence of kanamycin were transformed with NPTII gene, and one plant among six growing in the presence of kanamycin contained LEM1 gene, with $4.3 \%$ and $1.43 \%$ of transformation efficiency, respectively, as indicated by PCR analysis. Colorimetric analysis of commercial fruits allowed to classify them into three groups: mainly green, mainly colored and partially colored. Ethylene production and enzymatic activity of ACCoxidase were measured and indicated that yellow passion fruit is an intermediary producer of ethylene and that ACCoxidase has a limited activity and needs cofactors to reach a maximum value.
\end{abstract}

Key-words: Passion fruit; organogenesis; Agrobacterium; ethylene; ACCO. 